\title{
AKTIVITAS ANTIOKSIDAN FRAKSI N-HEKSANA TUMBUHAN PATAH TULANG (EUPHORBIA TIRUCALLI)
}

\author{
Ema Via Mawadah*, Arsyik Ibrahim, Lizma Febrina, Rolan Rusli \\ Laboratorium Penelitian dan Pengembangan FARMAKA TROPIS, Fakultas Farmasi \\ Universitas Mulawarman, Samarinda, Kalimantan Timur \\ *email :viaemafm@gmail.com
}

\begin{abstract}
ABSTRAK
Telah dilakukan penelitian mengenai aktivitas antiokidan fraksi n-heksana tumbuhan Patah Tulang (Euphorbia tirucalli) secara KLT Bioautografi. Hasil rendemen dari ektrak tumbuhan Patah Tulang adalah 8,576\%, sedangkan rendemen fraksi n-heksana adalah $5,502 \%$. Hasil uji fitokimia menunjukkan bahwa ekstrak metanol tumbuhan Patah Tulang mengandung steroid, tanin dan fenolik, sedangkan fraksi n-heksana mengandung steroid. Hasil dari uji aktivitas antioksidan fraksi n-heksana tumbuhan patah tulang menunjukkan adanya warna kuning pada spot noda yang telah disemprotkan DPPH, yang menunjukkan bahwa tumbuhan ini berpotensi memiliki aktivitas antioksidan.
\end{abstract}

Kata Kunci : Patah Tulang (Euphorbia tirucalli), Metabolit Sekunder, Antioksidan

\begin{abstract}
We report the activity of antioxidants fraction of $n$-hexane Patah Tulang plant (Euphorbia tirucalli) by TLC Bioautografi. The results yield from extracts Patah Tulang plant was $8.576 \%$, while the yield of n-hexane fraction was $5.502 \%$. Phytochemical test results showed that the methanol extract of Patah Tulang plant contain steroids, tannins and phenolics, while the n-hexane fraction containing steroids. The results of the test the antioxidant activity of n-hexane fraction Patah Tulang plant showed yellow stains on the spot that has been sprayed DPPH, which indicates that this plant has the potential to have antioxidant activity.
\end{abstract}

Keywords : Patah Tulang (Euphorbia tirucalli), Secondary Metabolites, Antioxidants

\section{PENDAHULUAN}

Patah tulang mempunyai berbagai macam nama berdasarkan daerah asalnya. Beberapa nama daerah patah tulang adalah ssusura (Sunda), kayu urip, pacing tawa, tikel balung (Jawa), kayu jaliso, kayu leso, kayu langtolangan, kayu tabar (Madura), patah tulang (Sumatera), kayu potong (Kaengan). Di daerah Kutai Timur patah tulang biasa disebut bunga pensil (Haryanto, 2012). Tanaman yang berasal dari Afrika tropis ini menyukai tempat terbuka yang terkena cahaya matahari langsung. Di Indonesia ditanam sebagai tanaman pagar, tanaman hias di pot, atau tumbuh liar dan dapat ditemukan dari dataran rendah sampai 600 meter di atas permukaan laut. Perdu, tumbuh tegak, tinggi 2-6 meter, pangkal berkayu, banyak bercabang, bergetah seperti susu yang beracun (Widyaningrum, 2011). 
Maserasi adalah proses pengekstrakan simplisia dengan menggunakan pelarut dengan beberapa kali pengocokan atau pengadukan pada temperatur ruangan (kamar). Secara teknologi termasuk ekstraksi dengan prinsip metode pencapaian konsentrasi pada keseimbangan. Maserasi kinetik berarti dilakukan pengadukan yang kontinu (terusmenerus). Remaserasi berarti dilakukan pengulangan penambahan pelarut setelah dilakukan penyaringan maserat pertama dan seterusnya (DITJEN POM, 2000). Proses fraksinasi menggunakan gradien konsentras dengn diaduk menggunakan magnetic stirrer.

Senyawa metabolit sekunder merupakan sumber bahan kimia alami yang dapat ditemukan di alam untuk dijadikan sebagai rujukan untuk pengembangan obat-obatan khususnya obat baru atau untuk menujang berbagai kepentingan industri. Bahan ini tidak akan pernah habis dan terus akan tercipta dengan struktur molekul yang mengalami interkonversi sejalan dengan perkembangan zaman. Dengan demikian senyawa yang bersumber dari alam akan terus ada tercipta baik yang sudah pernah ditemukan maupun yang baru dan belum diketemukan (Darminto, 2009).

Senyawa antioksidan sintetik (sekunder) memiliki fungsi menangkap radikal bebas dan menghentikan reaksi berantai, berikut adalah contoh antioksidan sintetik: Butylated hydroxyl anisole (BHA), Butylated hydroxyrotoluene (BHT), Propyl gallate (PG) dan metal chelating agent (EDTA), Tertiary butyl hydroquinone (TBHQ), Nordihydro guaretic acid (NDGA). Antioksidan utamapada saat ini digunakan dalam produk makanan adalah monohidroksi atau polihidroksi senyawa fenol dengan berbagai substituen pada cincin (Hamid, 2010).

Tujuan dari penelitian ini adalah untuk mengetahui apakah fraksi n-heksana tumbuhan Patah Tulang (Euphorbia tirucalli) memiliki aktivitas antioksidan atau tidak.

\section{METODE PENELITIAN}

\section{Bahan}

Batang patah tulang, metanol, n-heksana, etil asetat, asam klorida pekat, serbuk magnesium, besi (III) klorida $1 \%$ dan 10\&, asam klorida $2 \mathrm{M}$, pereaksi Dragendroff, pereaksi Mayer, aquades, asam asetat glasial, asam sulfat pekat dan DPPH 40 ppm.

\section{Peralatan}

Seperangkat alat maserasi, seperangkat alat fraksinasi, desikator, rotary evaporator, timbangan analitik, plat KLT, pipa kapiler.

\section{Prosedur}

\section{Penyiapan Sampel}

Sampel yang digunakan adalah batang patah tulang (Euphorbia tirucalli) yang masih segar dan tidak rusak. Tahap awal adalah pengumpulan bahan. Setelah pengumpulan bahan, dilakukan sortasi basah dengan menyeleksi bagian tanaman yang tidak digunakan seperti kotoran dari luar. Kemudian ditimbang dan dicuci dengan air mengalir. Dirajang dan dikeringkan sampel dengan cara diangin-anginkan pada suhu kamar dan terlindung dari cahaya matahari. Dilakukan sortasi kering dengan cara menyeleksi pengotor yang mungkin terikut, lalu disimpan.

\section{Ekstraksi dan Fraksinasi Sampel}

Simplisia batang patah tulang diekstraksi dengan metode maserasi menggunakan pelarut metanol sehingga diperoleh bagian residu dan bagian maserat. Proses maserasi dilakukan dalam wadah yang tertutup rapat (toples). Toples didiamkan \pm 24 jam dengan sesekali diaduk. Proses maserasi diulangi beberapa kali sampai pelarut metanol berwarna 
jernih. Ekstrak batang patah tulang kemudian dipisahkan dari pelarut metanol menggunakan rotary evaporator sehingga diperoleh ekstrak kental. Ekstrak kental selanjutnya diuapkan diatas water bath untuk memperoleh ekstrak kering dan kasar batang patah tulang.

Proses fraksinasi menggunakan gradien konsentrasi, dimana pelarut ditambahakn kedalam ekstrak yang sudah ditimbang lalu distirrer. Proses dilakukan berulang hingga ekstrak bening.

Dihitung hasil rendemen ekstrak dan fraksi tumbuhan patah tulang dengan rumus sebagai berikut:

$$
\% \text { Rendemen }=\frac{\text { Jumlah berat sampel akhir }}{\text { Jumlah berat sampel awal }} \times 100 \%
$$

\section{Uji Metabolit Sekunder}

\section{a. Uji Alkaloid}

Sebanyak $2 \mathrm{~mL}$ ekstrak diuapkan di atas cawan porselin. Residu yang dihasilkan kemudian dilarutkan dengan $5 \mathrm{~mL} \mathrm{HCl} 2 \mathrm{M}$. Larutan yang diperoleh dibagi ke dalam 3 tabung reaksi. Tabung pertama berfungsi sebagai blanko, ditambahkan dengan 3 tetes $\mathrm{HCl}$ 2 M. Tabung kedua ditambahkan 3 tetes pereaksi Dragendorff dan tabung ketiga ditambahkan 3 tetes pereaksi Mayer. Pada pereaksi Dragendorff akan terbentuk endapan berwarna jingga sedangkan pereaksi Mayer akan terbentuk endapan kuning yang menandakan positif adanya alkaloid.

\section{b. Uji Fenolik}

Ekstrak sampel sebanyak $1 \mathrm{ml}$

dimasukkan ke dalam tabung reaksi untuk dilakukan pengujian fenolik dengan cara ekstrak ditambahkan pereaksi $\mathrm{FeCl}_{3} 1 \%$, jika terjadi warna hitam menunjukkan adanya senyawa fenolik.

\section{c. Uji Flavonoid}

Sebanyak $2 \mathrm{~mL}$ ekstrak ditambahkan dengan air panas secukupnya, kemudian dididihkan selama 5 menit lalu disaring. Filtrat sebanyak $5 \mathrm{~mL}$ ditambahkan $0,05 \mathrm{mg}$ serbuk $\mathrm{Mg}$ dan $1 \mathrm{~mL} \mathrm{HCl}$ pekat, kemudian dikocok kuat-kuat. Uji positif ditunjukkan dengan terbentuknya warna merah, kuning atau jingga.

\section{d. Uji Tanin}

Sebanyak $1 \mathrm{~mL}$ ekstrak ditambahkan dengan beberapa tetes larutan besi(III)klorida $10 \%$. Jika terjadi warna biru tua atau hitam kehijauan menunjukkan adanya tannin.

\section{e. Uji Steroid}

Sebanyak 2 mL ekstrak ditambahkan $\mathrm{CH}_{3} \mathrm{COOH}$ glasial sebanyak 10 tetes dan $\mathrm{H}_{2} \mathrm{SO}_{4}$ pekat sebanyak 2 tetes. Larutan dikocok perlahan dan dibiarkan selama beberapa menit. Adanya steroid ditunjukan oleh warna biru atau hijau, sedangkan triterpenoid memberikan warna merah atau ungu.

\section{f. Uji Saponin}

Sebanyak 2-3 mL ekstrak dimasukkan ke dalam tabung reaksi, kemudian ditambahkan $10 \mathrm{~mL}$ air panas lalu didinginkan, kemudian dikocok kuat-kuat selama 10 detik lalu ditambahkan 1tetes $\mathrm{HCl} 2 \mathrm{~N}$. Uji positif ditunjukkan dengan terbentuknya buih yang stabil setinggi $1-10 \mathrm{~cm}$ selama tidak kurang dari 10 menit. 


\section{Uji Aktivitas Antioksidan}

Ekstrak yang dihasilkan dalam proses fraksinasi, kemudian dilakukan uji peredaman radikal bebas untuk mengetahui aktivitas antioksidan fraksi n-heksana Euphorbia tirucalli secara kualitatif. Uji ini menggunakan metode Kromatografi Lapis Tipis (KLT) dengan cara menotolkan ekstrak pada plat KLT kemudian dielusi dengan menggunakan campura $\mathrm{n}$ heksana:etil asetat (7:3). Plat KLT dikeringkan dan disemprot dengan larutan 0,004\% 1,1 difenil 2 pikrilhidrazil (DPPH) dalam metanol. Setelah 30 menit plat KLT diamati, uji positif sebagai antioksidan apabila terjadi perubahan warna pada plat KLT dari warna ungu berubah putih kekuningan dengan latar ungu disekitar spot.

\section{HASIL DAN PEMBAHASAN}

\section{Ekstraksi dan Fraksinasi Patah Tulang}

Penelitian ini menggunakan batang patah tulang sebanyak $3 \mathrm{~kg}$ dan dibuat simplisia. Sampel segar dilakukan proses sortasi, pencucian, perajangan, pengeringan. Proses sortasi dan pencucian dilakukan untuk memisahkan kotoran-kotoran atau bahan asing lainnya dari simplisia menggunakan air bersih. Perajangan dilakukan untuk memudahkan dalam proses pengeringan, karena semakin kecil simplisia proses pengeringannya juga lebih maksimal. Pengeringan sendiri bertujuan untuk mendapatkan simplisia yang tidak mudah dirusak oleh adanya pertumbuhan jamur sehingga dapat disimpan dalam waktu yang lebih lama. Dengan mengurangi kadar air dan menghentikan reaksi enzimatik akan dicegah penurunan mutu dan perusakan simplisia. Dari $3 \mathrm{~kg}$ sampel segar, didapatkan 415,12 gram simplisa

Ekstraksi patah tulang menggunakan cara dingin yaitu maserasi. Alasan pemilihan metode maserasi karena mempunyai banyak keuntungan dibandingkan dengan metode lain. Keuntungannya yaitu prosedur dan alat yang digunakan sederhana, tidak menggunakan pemanasan sehingga senyawa yang terkandung di dalamnya tidak akan rusak atau terurai, pelarut yang digunakan juga lebih sedikit dibandingkan dengan cara dingin lainnya yaitu perkolasi. Pelarut yang digunakan untuk maserasi adalah metanol. Digunakan metanol karena sifatnya yang semi polar, sehingga dapat melarutkan hampir semua senyawa baik polar maupun non polar.

Proses fraksinasi dilakukan dengan menggunakan gradien konsentrasi dengan magnetic stirrer. Kelebihan dari fraksinasi ini yaitu, hasil yang didapatkan lebih banyak dan lebih cepat, serta tidak perlu menggunakan tambahan air seperti pada fraksinasi padat-cair, dan pelarut yang digunakan lebih sedikit tidak seperti fraksinasi padat-cair.

Perhitungan rendemen ini bertujuan untuk mengetahui jumlah ekstrak maupun hasil fraksi dalam hitungan persen. Sehingga dapat diketahui jika menggunakan x gram simplisia, akan didapatkan ekstrak sebesar y gram.

Tabel 1. Rendemen Ekstrak dan Fraksi Patah Tulang

\begin{tabular}{lcc}
\hline \multicolumn{1}{c}{ Sampel } & Berat (gram) & \% Rendemen \\
\hline Ekstral & 35,6 & $8,576 \%$ \\
Fraksi N-Heksana & 22,84 & $5,502 \%$ \\
\hline
\end{tabular}

Berdasarkan tabel diatas dapat dilihat bahwa, dari simplisia sebesar 415,12 gram didapatkan ekstrak sebanyak 35, 6 gram sehingga rendemen yang dihasilkan adalah 8,576\%. Dan hasil fraksinasi dengan menggunakan pelarut N-Heksana didapatkan hasil yaitu 22,84 gram sehingga rendemen yang dihasilkan adalah 5,502\%. 


\section{Uji Metabolit Sekunder}

Analisis fitokimia merupakan salah satu cara untuk mengetahui kandungan metabolit sekunder pada suatu tanaman secara kualitatif. Analisis fitokimia ada penelitian ini dilakukan terhadap tanaman patah tulang yang sudah dimaserasi menggunakan pelarut metanol dan di fraksinasi menggunakan pelart N-Heksana. Pengujiannya dilakukan dengan cara mengambil sedikit sampel dari kedua ekstrak tersebut, lalu ditambahkan reagen sesuai dengan senyawa yang akan diidentifikasi. Senyawa-senyawa yang diperiksa keberadaannya adalah alkaloid, flavonoid, tanin, fenolik, saponin dan steroid/triterpenoid.

Hasil uji metabolit sekunder menunjukkan bahwa ekstrak metanol patah tulang mengandung steroid, tanin dan fenol. Sedangkan untuk fraksi N-heksana patah tulang hanya mengandung steroid.

Tabel 2. Kandungan Metabolit Sekunder Ekstrak dan Fraksi Patah Tulang

\begin{tabular}{lcc}
\hline \multicolumn{1}{c}{ Uji Metabolit Sekunder } & Ekstrak & Fraksi N-Heksana \\
\hline Alkaloid a. Dragendroff & - & - \\
b. Mayer & - & - \\
Flavonoid & - & - \\
Steroid & + & + \\
Tanin & + & - \\
Fenolik & + & - \\
Saponin & - & - \\
\hline
\end{tabular}

Keterangan : (-) tidak mengandung senyawa, (+) mengandung senyawa

Hasil uji senyawa alkaloid, masing-masing ekstrak dan fraksi terlebih dahulu dilarutkan dalam asam klorida yang bertujuan agar senyawa alkaloid yang bersifat basa dapat berikatan dengan asam. Kemudian pada masing-masing ekstrak dan fraksi ditambahkan pereaksi Mayer dan Dragendroff. Dari keduanya hasil yang didapatkan adalah negatif yang ditandai dengan tidak terbentuknya endapan.

Uji senyawa flavonoid menggunakan serbuk $\mathrm{Mg}$ dan $\mathrm{HCl}$ pekat. Hasil menunjukkan ekstrak metanol dan fraksi n-heksana tidak mengandung flavonoid

Uji senyawa steroid menunjukkan hasil yang positif. Dimana ekstrak metanol dan fraksi N-Heksana menunjuukan perubahan warna biru setelah penambahan asam asetat glasial dan $\mathrm{H}_{2} \mathrm{SO}_{4}$ pekat.

Uji senyawa tanin menunjukkan hasil yang positif untuk ekstrak metanol. Dimana terbentuk warna hijau kehitaman setelah ditambahkan $\mathrm{FeCl}_{3} 10 \%$.

Uji senyawa fenolik menunjukkan hasil yang positif untuk ekstrak metanol. Dimana terbentuk warna biru kehitaman setelah ditambahkan $\mathrm{FeCl}_{3} 1 \%$.

Uji senyawa saponin menunjukkan hasil yang negatif baik ekstrak metanol maupun fraksi N-Heksana, dimana tidak terbentuknya busa setelah dikocok selama 10 menit.

\section{Uji Aktivitas Antioksidan}

Uji aktivitas antioksidan dilakukan pada fraksi N-Heksana menggunakan lempeng Kromatografi Lapis Tipis (KLT). Fraksi N-Heksana ditotolkan pada plat KLT, lalu 
disemprotkan dengan DPPH. Lalu diamati perubahan warna di plat KLT dari warna ungu menjadi kuning pada spot nodanya.

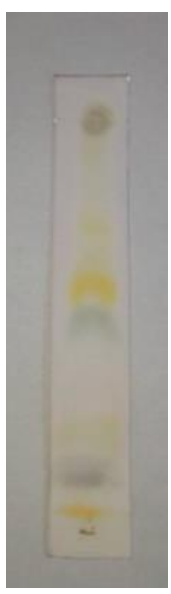

Gambar 1. Pengujian Aktivitas Antioksidan

Warna kuning pada spot noda yang telah disemprotkan DPPH, menunjukkan bahwa tumbuhan ini berpotensi memiliki aktivitas antioksidan.

\section{KESIMPULAN}

Pada penelitian ini didapatkan kesimpulan bahwa rendemen ekstrak dan fraksi NHeksana patah tulang adalah $8,58 \%$ dan $5,50 \%$. Hasil uji metabolit sekunder menunjukkan bahwa ekstrak metanol patah tulang mengandung steroid, tanin dan fenolik. Sedangkan untuk fraksi N-heksana patah tulang hanya mengandung steroid. Serta tumbuhan patah tulang berpotensi sebagai antioksidan.

\section{DAFTAR PUSTAKA}

Darminto. 2009 . Indentifikasi Senyawa Metabolit Sekunder Potensial Menghambat Pertumbuhan Bakteri Aeromonas hydrophyla dari Kulit batang Tumbuhan Aveccennia spp. Jurnal Chemica. Vol. 10 Nomor 2

DITJEN POM. 2000. Parameter Standar Umum Ekstrak Tumbuhan Obat. Jakarta : Departemen Kesehatan RI Direktorat Jenderal Pengawasan Obat dan Makanan Direktorat Pengawasan Obat Tradisional

Hamid, et all. 2010. Antioxidants: Its medicinal and pharmacological Applications. African Journal of Pure and Applied Chemistry Vol. 4(8), pp. 142-151

Harborne, J.B., 1987. Metode Fitokimia : Penuntun Cara Modern Menganalisis Tumbuhan Edisi Kedua. ITB. Bandung.

Harborne, J.B., 2006. Metode Fitokimia Edisi Kedua. Penerbit ITB. Bandung.

Haryanto, Sugeng. 2012. Ensiklopedia Tanaman Obat. Yogyakarta: Palmall 
Pramesti, Rini. 2013. Aktivitas Antioksidan Ekstrak Rumput Laut Caulerpa serrulata Dengan Metode DPPH (1,1 difenil 2 pikrilhidrazil). Buletin Oseanografi Marina. Volume 2. Nomor 7-15.

Widyaningrum, Herlina. 2011. Kitab Tanaman Obat Nusantara. Yogyakarta : Media Pressindo 